\title{
Leaders
}

\section{Recent advances in immunohistochemistry in the diagnosis of ovarian neoplasms}

\author{
W G McCluggage
}

\begin{abstract}
This leader reviews recent advances in immunohistochemistry that are useful in the diagnosis of ovarian neoplasms. These include the value of different anticytokeratin antibodies in the distinction between a primary ovarian adenocarcinoma and a metastatic adenocarcinoma, especially of colorectal origin. These antibodies have also helped to clarify the origin of the peritoneal disease in most cases of pseudomyxoma peritonei. The value of antibodies against so called tumour specific antigens, such as CA125 and HAM56, in determining the ovarian origin of an adenocarcinoma is also reviewed. In recent years, several studies have investigated the value of a variety of monoclonal antibodies in the diagnosis of ovarian sex cord stromal tumours and in the distinction between these neoplasms and their histological mimics. These antibodies include those directed against inhibin, CD99, Mullerian inhibiting substance, relaxin like factor, melan $A$, and calretinin. Of these, anti- $\alpha$ inhibin appears to be of most diagnostic value. It is stressed that these antibodies should always be used as part of a larger panel and not in isolation.

(F Clin Pathol 2000;53:327-334)
\end{abstract}

Keywords: ovarian neoplasms; diagnosis; immunohistochemistry

Primary ovarian neoplasms comprise a heterogeneous group of tumours of three main subtypes, namely surface epithelial, germ cell, and sex cord stromal. The wide morphological variation within and between these groups can result in diagnostic difficulties, with tumours in one group mimicking those in another. In general, there are few problems in diagnosing an epithelial tumour, although confusion can arise between a primary ovarian adenocarcinoma and a secondary adenocarcinoma, especially of large intestinal origin. There might also be difficulties in distinguishing between an ovarian endometrioid carcinoma and a sex cord stromal tumour of Sertoli or granulosa cell type. Confusion might also arise between sex cord stromal tumours and a wide variety of other neoplasms. Recent advances in immuno- histochemistry have assisted in these diagnostic difficulties and are reviewed in this leader. Immunohistochemistry has also clarified the origin of the peritoneal disease in most cases of pseudomyxoma peritonei. Although a large number of immunohistochemical studies have investigated possible prognostic markers in ovarian tumours, mostly of surface epithelial type, the results are sometimes contradictory and most are not in widespread use. Therefore, these are not reviewed in this article.

Role of anticytokeratin antibodies in distinction between primary and secondary ovarian adenocarcinoma The morphological distinction between a primary ovarian adenocarcinoma, usually of mucinous or endometrioid subtype, and a metastatic adenocarcinoma, especially of colorectal origin, can be extremely difficult. Especially with mucinous neoplasms, metastatic adenocarcinomas can contain areas resembling benign or borderline tumour. Histological features have been described that facilitate this distinction between primary and secondary tumour, ${ }^{1-3}$ but in some cases it might be difficult or impossible to decide with certainty. So called specific tumour associated antigens (discussed later) might be of some value but these are often not, in fact, specific to a particular site of origin and their value is limited. Epithelia from different sites differ in their pattern of keratin expression and this pattern is often, but importantly not always, maintained in the corresponding carcinomas. Recent studies have investigated the value of anticytokeratin (anti-CK) antibodies in the distinction between an ovarian primary and a metastatic carcinoma, especially of colorectal origin. ${ }^{4-8}$ Primary ovarian adenocarcinomas, including those of mucinous and endometrioid types, are usually CK7 positive (fig 1A) and might be CK20 positive or negative (usually negative) (fig 1B), whereas colorectal adenocarcinomas are generally CK7 negative and CK20 positive (fig 2). However, caution should be exercised because occasional colorectal adenocarcinomas are $\mathrm{CK} 7$ positive and some primary ovarian adenocarcinomas, especially of mucinous type, are $\mathrm{CK} 7$ negative. It is stressed that when using anti-CK antibodies to assist in the distinction between a primary and 


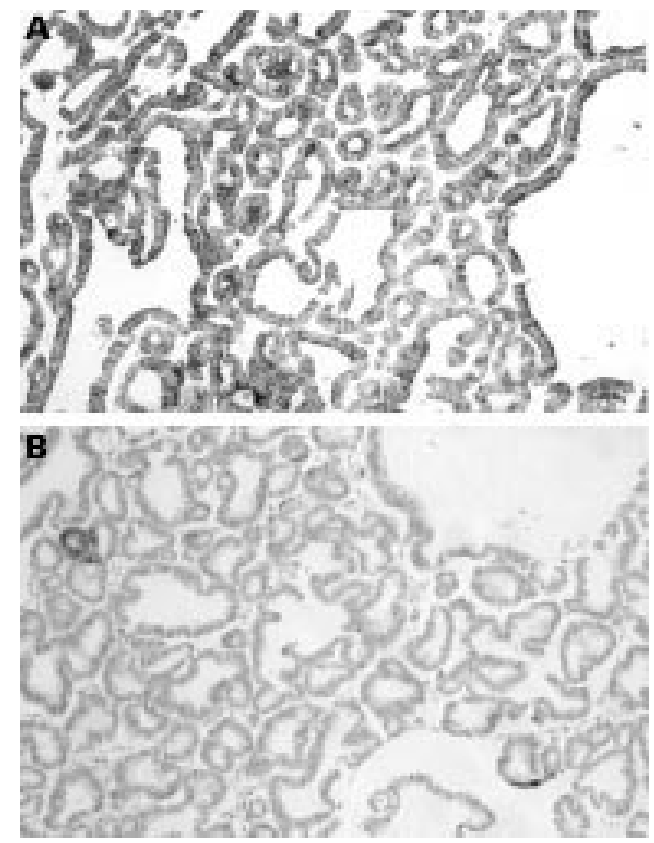

Figure 1 (A) Primary ovarian mucinous adenocarcinoma in which there is strong positive staining for cytokeratin 7 (CK7). (B) Same primary ovarian mucinous adenocarcinoma showing no staining for CK20.

secondary adenocarcinoma there should always be close correlation with the morphological features. Be that as it may, the pattern of staining with antibodies to CK7 and CK20 might be of value in the distinction. The value of these antibodies is probably greater in the distinction between a primary ovarian endometrioid carcinoma and a secondary than in the case of a primary ovarian mucinous carcinoma because the latter might be CK7 negative and/or CK20 positive. $^{7}$ The value of anti-CK antibodies might be increased when used as part of a larger panel, which may include antibodies to carcinoembryonic antigen (CEA), CA125, and CA19.9. Table 1 is a suggested panel that might facilitate the distinction between a primary ovarian adenocarcinoma and a metastatic tumour of colorectal origin. In general, anti-CK antibodies are of no value in distinguishing between a primary ovarian adenocarcinoma and a metastasis from the breast, stomach, pancreas, or endometrium because these neoplasms usually also exhibit CK7 positivity. This is important because metastasis from these neoplasms might also closely mimic a primary ovarian adenocarcinoma, especially of mucinous type.

\section{Role of immunohistochemistry in determining origin of pseudomyxoma peritonei}

Pseudomyxoma peritonei (PMP) is a condition characterised by mucinous ascites and the presence of multifocal mucinous tumours within the peritoneal cavity. Women with PMP may have mucinous tumours of the ovary and appendix and there has been debate regarding the origin of PMP in such cases, with conflicting opinions based on gross and microscopic pathological features. ${ }^{9-13}$ Some have concluded that the ovarian tumour is usually a metastasis

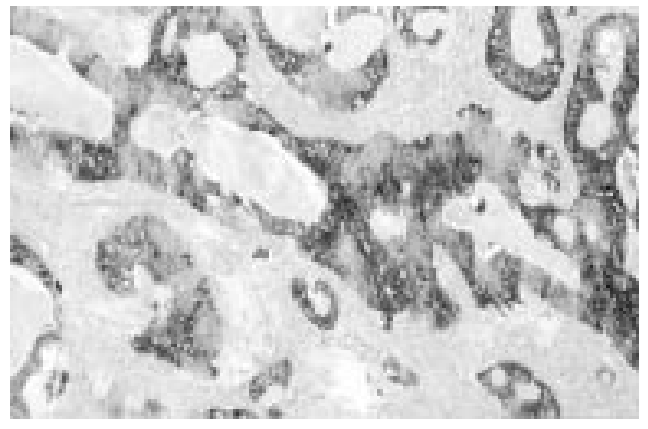

Figure 2 Metastatic colonic adenocarcinoma in ovary exhibiting strong positive staining for cytokeratin 20 (CK20).

from the appendiceal neoplasm, whereas others consider the ovarian and appendiceal lesions to be independent primaries. The ovarian tumour is often interpreted as a primary mucinous cystadenocarcinoma or as a primary mucinous tumour of low malignant potential (borderline tumour). As stated earlier, most primary ovarian mucinous tumours are CK7 positive, whereas most colorectal adenocarcinomas are CK7 negative and CK20 positive. Recent studies using these anti-CK antibodies have found that most appendiceal mucinous tumours are also CK7 negative and CK20 positive, as would be expected, although a small number might be CK7 positive. ${ }^{14}{ }^{15}$ These studies have suggested that in most cases of PMP with concomitant ovarian and appendiceal neoplasms, the PMP is of appendiceal origin (CK7 negative, CK20 positive). Furthermore, in most of these cases, the ovarian neoplasm has an identical immunophenotype, suggesting that it represents a metastasis from the appendix. Similarly, other studies using molecular genetic techniques have demonstrated that most, but not all, synchronous mucinous tumours of the ovary and appendix are of appendiceal origin. ${ }^{16}{ }^{17}$ I have recently seen a case of a presumed primary ovarian mucinous borderline tumour associated with PMP where a primary appendiceal mucinous tumour only became manifest one year later. It is recommended that in all cases of PMP associated with an ovarian mucinous tumour (even a presumed primary ovarian benign or borderline mucinous tumour), CK7 staining should be performed and, if negative, a primary appendiceal tumour should be strongly suspected. In such cases, the appendix can be macroscopically normal or can be obliterated by the fibrosis that often accompanies PMP, and a mucinous tumour might only be identified after surgical removal and histological examination. The finding of CK7 positivity within the PMP in such cases is less useful, and correlation with clinical, pathological, and other immunohistochemical findings is necessary to determine the origin of the PMP.

Value of antibodies against tumour specific antigens in determining ovarian origin of adenocarcinoma

Monoclonal antibodies raised against tumour associated antigens have been investigated as a means of diagnosing cancer, including ovarian 
Table 1 Immunohistochemical panel of value in distinction between primary ovarian and colorectal adenocarcinoma

\begin{tabular}{|c|c|c|c|}
\hline Antigen & $\begin{array}{l}\text { Non-mucinous ovarian } \\
\text { adenocarcinoma }\end{array}$ & $\begin{array}{l}\text { Ovarian mucinous } \\
\text { adenocarcinoma }\end{array}$ & Colorectal adenocarcinoma \\
\hline CK7 & Usually positive & Usually positive & Usually negative \\
\hline CK20 & Usually negative & Positive or negative & Usually positive \\
\hline HAM56 & Usually positive & Positive or negative & Usually negative \\
\hline CA125 & Usually positive & Usually negative & Can be focally positive \\
\hline CEA & Can be focally positive & Positive or negative & Usually positive \\
\hline
\end{tabular}

CEA, carcinoembryonic antigen; CK, cytokeratin; HAM, human alveolar macrophage.

carcinoma. In general, in the case of ovarian cancer these have not proved to be sufficiently specific, and their value is limited in a diagnostic sense. Human alveolar macrophage 56 (HAM56), a monoclonal antibody reactive against macrophages and endothelial cells, has been proposed as a useful marker in distinguishing between primary ovarian adenocarcinoma and metastatic adenocarcinoma, especially of colorectal origin. Primary ovarian adenocarcinomas are usually HAM56 positive whereas colorectal adenocarcinomas are usually negative. ${ }^{18-22}$ However, although the results of studies are somewhat conflicting, it is clear that positivity for HAM56 may be present in a large proportion of colorectal adenocarcinomas, as well as primary adenocarcinomas arising at other sites. Although positivity is found in a higher proportion of ovarian adenocarcinomas than those arising primarily at other sites, this antibody is not specific for an ovarian primary, and in individual cases is of limited value when confronted with an adenocarcinoma of unknown origin. However, HAM56 may be used as part of a larger panel.

Similarly, other studies have investigated the use of antibodies such as those directed against CEA and CA125 in distinguishing between a primary ovarian adenocarcinoma and one of extraovarian origin..$^{53-28}$ These antibodies are not specific to a particular site of origin and are of limited diagnostic value. CA125 is a useful biochemical marker of ovarian carcinoma, ${ }^{29}$ and there is diffuse strong positive immunohistochemical staining in most non-mucinous ovarian adenocarcinomas (fig 3), but often no staining in primary ovarian mucinous tumours. In addition, primary colorectal adenocarcinomas and adenocarcinomas at other sites might be positive, albeit often focally, limiting the value of CA125 as a diagnostic discriminator. CA125 is also positive in most mesotheliomas, ${ }^{30}$ which can be confused with ovarian type serous adenocarcinomas, either of ovarian

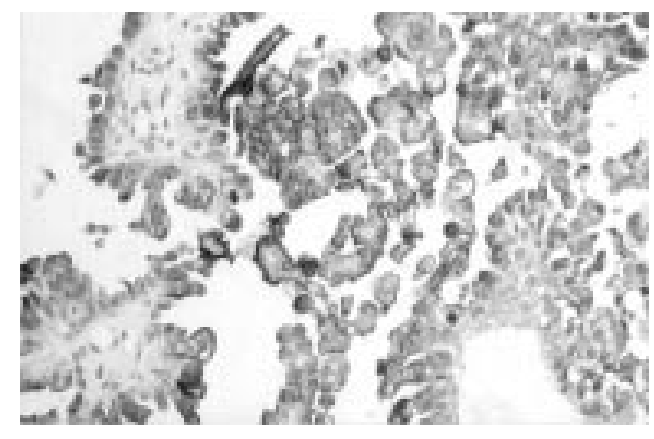

Figure 3 Strong positive staining of ovarian serous adenocarcinoma for $C A 125$. or peritoneal origin, when associated with multifocal peritoneal tumour deposits. A recent study using six monoclonal antibodies, including anti-CA125, in an attempt to distinguish between a primary ovarian and colorectal adenocarcinoma concluded that most ovarian carcinomas, including those of mucinous type, can be discriminated with high probability from a colorectal carcinoma using a panel of three antibodies directed against CEA, CK7, and vimentin. ${ }^{5}$

The search for a monoclonal antibody specific to ovarian adenocarcinoma continues and, as yet, no specific marker has been found. Antibodies such as MX35, OV-TL3, and MOV18 have been developed but have not yet become established in a diagnostic setting. ${ }^{31} 32$ A recently developed monoclonal antibody SMO47 reacts with most ovarian adenocarcinomas, but positivity can also be found in primary adenocarcinomas arising at other sites, although in these cases usually with a more limited distribution. It is stressed that in problematic cases, careful morphological examination combined with immunostaining using a panel of antibodies that will vary, depending on the differential diagnosis under consideration, should allow for a correct diagnosis in most instances.

Immunohistochemistry in the diagnosis of ovarian sex cord stromal tumours

Sex cord stromal tumours are relatively rare, accounting for approximately $4 \%$ of benign ovarian neoplasms and $7 \%$ of primary ovarian malignancies. ${ }^{33}$ They have a varied histological appearance and can mimic a wide range of other ovarian neoplasms, both benign and malignant. Sertoli-Leydig cell tumours and granulosa cell tumours can closely resemble ovarian endometrioid adenocarcinomas, and the juvenile variant of granulosa cell tumour might be difficult to distinguish from small cell carcinoma of hypercalcaemic type. Other neoplasms that might resemble sex cord stromal tumours include endometrial stromal sarcoma, undifferentiated carcinoma, carcinoid tumour, desmoplastic small round cell tumour, Brenner tumour, and germ cell neoplasms. ${ }^{34}$ Although antibodies reactive against cytoplasmic intermediate filaments such as CKs and vimentin might be useful in some situations, these lack sufficient diagnostic specificity, and until recently there have been no specific immunohistochemical markers of sex cord stromal differentiation. However, in the past few years a large number of studies have investigated the value of several monoclonal antibodies in the diagnosis of ovarian sex cord stromal tumours and in their distinction from histological mimics. These antibodies are reviewed in the next few sections.

\section{INHIBIN}

Inhibin is a dimeric $32 \mathrm{kDa}$ peptide hormone composed of an $\alpha$ subunit and a $\beta$ subunit. ${ }^{35}$ The $\beta$ subunit may be of the A or B type, giving rise to two forms of inhibin (A and $\mathrm{B}$ ) of apparently identical biological activity. The hormone is produced by ovarian granulosa 


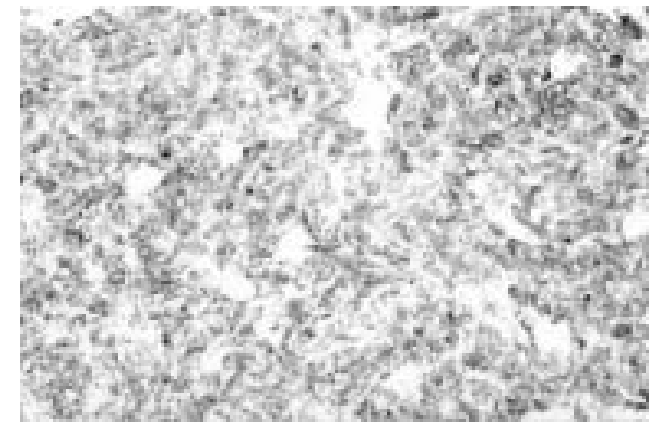

Figure 4 Strong positive staining of adult granulosa cell tumour for a inhibin.

cells and inhibits the release of follicle stimulating hormone from the pituitary gland, thus acting as a modulator of folliculogenesis. ${ }^{36}$ Inhibin is also produced by testicular Sertoli cells, and extragonadal expression has been demonstrated in the placenta, adrenal gland, pituitary gland, and liver. ${ }^{37-42}$ As well as being produced normally by granulosa cells, inhibin is also produced by granulosa cell tumours, and serum measurements can be used to monitor these neoplasms. Raised serum inhibin values can indicate recurrent or metastatic disease before it becomes clinically apparent. $^{43} 44$

In recent years, immunohistochemical staining with anti-inhibin antibodies has been performed on tissue sections. Several studies have found that antibodies against inhibin, especially against the $\alpha$ subunit, are useful immunohistochemical markers of ovarian sex cord stromal tumours, especially granulosa cell tumours. ${ }^{45-58}$ Most ovarian sex cord stromal tumours of all histological types stain positively with anti- $\alpha$ inhibin, and this might be of value in their distinction from other neoplasms that might mimic them, especially endometrioid type adenocarcinoma with a sex cord stromal pattern, undifferentiated carcinoma, and small cell carcinoma of hypercalcaemic type. Positive staining for $\alpha$ inhibin in these tumours, and in other primary and secondary ovarian adenocarcinomas, is usually confined to nonneoplastic ovarian stromal theca cells. ${ }^{59}$ This might account for the modest rise in serum inhibin concentrations sometimes seen in these patients, especially those with mucinous adenocarcinomas. ${ }^{60}$ However, caution should be exercised in that primary ovarian adenocarcinomas, as well as extraovarian adenocarcinomas, might occasionally exhibit positivity for $\alpha$ inhibin. A recent study found 20 of 78 adenocarcinomas from various sites to be positive for $\alpha$ inhibin. ${ }^{61}$ However, in these cases positive staining is generally weak, contrasting with the

Table 2 Immunohistochemical panel of value in the distinction between ovarian sex cord stromal tumour and endometrioid adenocarcinoma with sex cord like pattern

\begin{tabular}{lll}
\hline Antigen & Ovarian sex cord stromal tumour & $\begin{array}{l}\text { Endometrioid ovarian adenocarcinoma with } \\
\text { sex cord like pattern }\end{array}$ \\
\hline CK7 & Negative & Positive \\
$\alpha$ Inhibin & Positive & Negative \\
EMA & Negative & Positive \\
CD99 & Positive or negative (most positive) & Positive or negative (most negative)
\end{tabular}

${ }^{\star}$ Except for retiform areas in Sertoli-Leydig cell tumours.

CK, cytokeratin; EMA, epithelial membrane antigen. usual strong positivity in ovarian sex cord stromal tumours (fig 4). In attempting to distinguish between an ovarian sex cord stromal neoplasm and an epithelial tumour, especially ovarian endometrioid adenocarcinoma, $\alpha$ inhibin is extremely useful when performed as part of a larger panel. This panel should include an antibody to epithelial membrane antigen (EMA) because this is almost invariably negative in ovarian sex cord stromal tumours but positive in most cases of adenocarcinoma. ${ }^{62}$ The detection of $\alpha$ inhibin immunoreactivity in an ovarian tumour that is EMA negative provides both sensitive and specific support for the diagnosis of a sex cord stromal neoplasm. ${ }^{50}$ It should be noted that anti-CK antibodies are of limited value in the distinction between a sex cord stromal and epithelial neoplasm because antibodies against broad spectrum CKs might be positive in sex cord stromal tumours. ${ }^{63}$ However, staining with anti-CK7 might be of value because a recent study has found this antibody to be positive in ovarian endometrioid adenocarcinomas but negative in sex cord stromal tumours, except for the retiform areas in Sertoli-Leydig cell tumours. ${ }^{54}$ Table 2 is a suggested panel that might assist in the distinction between an ovarian sex cord stromal tumour and an endometrioid adenocarcinoma with a sex cord like pattern. A recent case study found that $\alpha$ inhibin staining was of value in confirming that a malignant spindle cell tumour within the ovary and intestine was a malignant ovarian fibrothecomatous tumour with intestinal metastasis. ${ }^{64}$ Positive staining with $\alpha$ inhibin has also been found in uterine tumours resembling ovarian sex cord tumours and in endometrial stromal tumours with sex cord like elements, supporting the hypothesis that these tumours might show true sex cord differentiation. ${ }^{65-67}$

Ovarian granulosa cell tumours are malignant neoplasms with a tendency to late recurrence or metastasis. When recurrent or metastatic disease develops, the history of removal of an ovarian granulosa cell tumour might not always be available. In such instances, immunostaining with anti- $\alpha$ inhibin might provide good evidence of a metastatic ovarian granulosa cell tumour. Positivity is found even in the sarcomatous variant, which might be confused with haemangiopericytoma and other mesenchymal neoplasms. Positive staining for $\alpha$ inhibin is also present in most juvenile granulosa cell tumours, and this might aid in the distinction of this neoplasm from its histological mimics, especially small cell carcinoma of hypercalcaemic type, which is invariably negative..$^{50}$

Staining for $\alpha$ inhibin has also been performed on cytological preparations and has been found to be of value in ovarian fine needle aspirates in the separation of functional cysts ( $\alpha$ inhibin positive) from epithelial lined cysts ( $\alpha$ inhibin negative). ${ }^{68}$ This separation is of some importance in that functional cysts can be observed, whereas epithelial lined cysts, even when benign, should probably be surgically removed. 


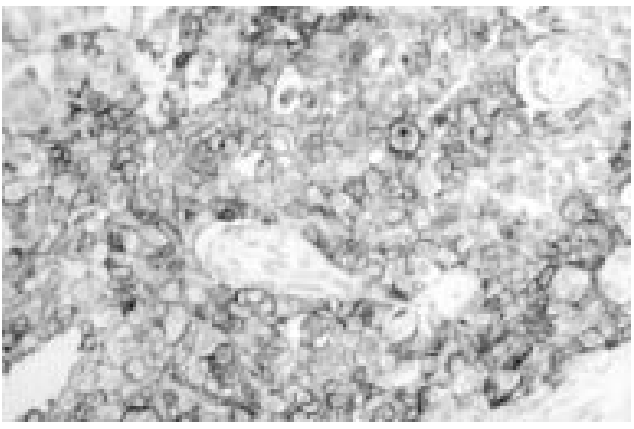

Figure 5 Strong membrane staining of a juvenile granulosa cell tumour with monoclonal antibody 013 (anti-CD99).

Immunostaining with antibodies against $\beta$ inhibin is of less diagnostic value than $\alpha$ inhibin because positivity might be found in a high proportion of primary ovarian adenocarcinomas. ${ }^{61}{ }^{69}$ Immunoreactivity might also be present in adenocarcinomas of diverse origins, and $\beta$ inhibin staining is of no value in determining the origin of an adenocarcinoma of unknown primary site. ${ }^{61}$

CD99

Monoclonal antibodies such as 013 , which react with the CD99 antigen (MIC2 gene product), are sensitive immunohistochemical markers of Ewing's sarcoma and peripheral primitive neuroectodermal tumour, and are in widespread use..$^{71}$ These antibodies also react with ovarian granulosa cells, ${ }^{72}$ and positivity has been demonstrated recently in ovarian sex cord stromal tumours of a variety of histological types (fig 5). ${ }^{46}{ }^{50} 72-74$ However, the proportion of tumours exhibiting positivity is less than for $\alpha$ inhibin, and some epithelial tumours may also be positive. In one study, $58 \%$ of small cell carcinomas of hypercalcaemic type were positive. $^{50}$ Therefore, it seems that CD99 is a less sensitive and specific marker than $\alpha$ inhibin in the confirmation of an ovarian sex cord stromal neoplasm, although it might be of value when used as part of a larger panel. It is stressed that, as in Ewing's sarcoma, only membranous staining for CD99 should be regarded as true positivity, and a cytoplasmic reaction should be considered negative for diagnostic purposes. Interestingly, a case of peripheral primitive neuroectodermal tumour of the ovary has been described that, as expected, was CD99 positive. ${ }^{75}$ Because the differential diagnosis in such a case might include small cell carcinoma of hypercalcaemic type and adult or juvenile granulosa cell tumour, positive staining for CD99 is of limited value. It is possible that, in the past, peripheral primitive neuroectodermal tumours that have arisen in the ovary have been misdiagnosed as small cell carcinoma. ${ }^{75}$ Similar to $\alpha$ inhibin, CD99 positivity has also been found in sex cord like elements in endometrial stromal tumours and in uterine tumours resembling ovarian sex cord tumours, supporting true sex cord differentiation. ${ }^{65-67}$
MELAN-A

The antibody A103, which reacts against the melan-A antigen, is widely used in the diagnosis of melanocytic disorders, positivity being found in most benign and malignant lesions. ${ }^{76}$ A103 immunoreactivity has been demonstrated recently in a small number of ovarian sex cord stromal tumours, positivity being found in three of four Sertoli-Leydig cell tumours. ${ }^{77}$ Clearly, the value of this antibody in ovarian sex cord stromal tumour diagnosis requires further investigation of a larger number of cases.

MULLERIAN INHIBITING SUBSTANCE

Mullerian inhibiting substance (MIS) is a homodimeric glycoprotein secreted by ovarian granulosa cells and testicular Sertoli cells. ${ }^{78}$ One of the functions of MIS is the regression of the Mullerian ducts during male fetal development. ${ }^{79}$ MIS can be demonstrated immunohistochemically in ovarian granulosa cells and raised serum concentrations have been found in patients with ovarian sex cord stromal tumours. ${ }^{81}$ Recently, an immunohistochemical study has shown the presence of MIS in all ovarian sex cord stromal tumours, although staining was not as strong or as diffuse as with anti- $\alpha$ inhibin. ${ }^{46}$ There was no staining of seven endometrioid adenocarcinomas resembling sex cord stromal tumours. This study found that two of the endometrioid adenocarcinomas were positive for CD99. Clearly, the value of immunohistochemical staining for MIS in confirmation of an ovarian sex cord stromal tumour has not been investigated as extensively as for $\alpha$ inhibin, and further studies are required before anti-MIS becomes accepted in routine diagnosis practice.

\section{RELAXIN LIKE FACTOR}

The relaxin like factor (RLF), also known as the Leydig cell insulin like peptide, is a hormone that is strongly expressed by testicular Leydig cells. ${ }^{82} \mathrm{~A}$ recent immunohistochemical study has shown expression of RLF in ovarian hilar Leydig cell hyperplasia and in ovarian sex cord stromal tumours with a component of Leydig or luteinised cells. ${ }^{83}$ RLF was not found in granulosa cell tumours, and neoplasms other than those of sex cord stromal type were not included in the study. The authors suggested that RLF might be a useful diagnostic tool in Leydig cell tumours but clearly this requires confirmation by further studies. Furthermore, Leydig cell tumours generally have a characteristic histological appearance and their distinction from other ovarian sex cord stromal tumours is usually not problematic.

\section{CALRETININ}

Calretinin is a $29 \mathrm{kDa}$ calcium binding protein that is a useful immunohistochemical marker of mesothelial cells and mesothelioma. ${ }^{84} \mathrm{Cal}-$ retinin positivity has been demonstrated recently in all cases of a small number of ovarian sex cord stromal tumours. ${ }^{84}$ However, because the number of cases studied is small, the value 
of this antibody in a diagnostic setting, as with anti-MIS and anti-RLF, needs to be confirmed by further investigations of larger numbers of cases.

\section{Miscellaneous}

This last section reviews several other recent developments in the immunohistochemistry of ovarian neoplasms that might be of use to the practising surgical pathologist.

Serum $\alpha$ fetoprotein $(\alpha \mathrm{FP})$ measurements and the demonstration of this protein immunohistochemically in tissue sections are useful in the diagnosis of an ovarian yolk sac tumour. However, positive staining and/or raised serum concentrations can also be found in ovarian sex cord stromal neoplasms, especially of SertoliLeydig origin, but also of other types. ${ }^{85-88} \mathrm{In}$ these cases, positivity might involve heterologous hepatoid cells, Sertoli cells, or Leydig cells. A recent report has described four ovarian granulosa cell tumours with foci of hepatic cell differentiation that were confirmed by positive immunohistochemical staining for $\alpha \mathrm{FP}^{89}$ Because sex cord stromal neoplasms might bear some morphological resemblance to yolk sac tumours, this raises obvious diagnostic problems, especially in a young patient, with implications for future management and treatment regimens. In such cases, staining for $\alpha$ inhibin might be useful because this generally appears to be negative in yolk sac tumours, although the number of cases studied is small. Positive immunohistochemical staining for $\alpha \mathrm{FP}$ (and raised serum concentrations) has also been demonstrated in ovarian endometrioid adenocarcinoma, a tumour that can also morphologically resemble a yolk sac tumour. $^{90}$

There are two distinct types of ovarian small cell carcinoma. The pulmonary type usually occurs in middle aged to elderly patients, and is morphologically and immunohistochemically identical to its pulmonary counterpart, exhibiting neuroendocrine differentiation. The hypercalcaemic type generally occurs in young women and is likely to be confused morphologically with granulosa cell tumour, especially the juvenile variant. The origin of small cell carcinoma of hypercalcaemic type has been debated, with an epithelial, stromal, or germ cell origin being proposed. ${ }^{91} \mathrm{~A}$ recent study showed EMA positivity in most cases, with all being $\alpha$ inhibin negative. ${ }^{50}$ The authors concluded that small cell carcinoma of hypercalcaemic type is probably a variant of surface epithelial tumour. Table 3 is a suggested immunohistochemical panel to facilitate the distinction between ovarian juvenile granulosa cell tumour and small cell carcinoma of hypercalcaemic type.

The so called female adnexal tumour of probable wolffian origin (FATWO) (which is most commonly situated within the broad ligament but which might occasionally occur within the ovary) is a tumour of uncertain histogenesis. An origin from wolffian remnants is suggested by its usual location in areas where these remnants are abundant, and this is supported by ultrastructural analysis. ${ }^{92} \mathrm{~A}$
Table 3 Immunohistochemical panel of value in the distinction between juvenile granulosa cell tumour and small cell carcinoma of hypercalcaemic type

\begin{tabular}{lll}
\hline Antigen & $\begin{array}{l}\text { fuvenile granulosa cell } \\
\text { tumour }\end{array}$ & $\begin{array}{l}\text { Small cell carcinoma of } \\
\text { hypercalcaemic type }\end{array}$ \\
\hline$\alpha$ Inhibin & Positive & Negative \\
CD99 & Usually positive & Positive or negative \\
EMA & Negative & Positive \\
\hline
\end{tabular}

EMA, epithelial membrane antigen.

recent imunohistochemical study provides support for the derivation of this tumour from wolffian remnants, the pattern of staining being nearly identical to that of the normal rete ovarii. ${ }^{93}$ Normal rete ovarii and FATWO coexpressed cytokeratin and vimentin and usually lacked immunoreactivity for EMA. Interestingly, most cases exhibited positive staining for $\alpha$ inhibin and calretinin. Inhibin positivity has also been noted in another study, ${ }^{56}$ suggesting that anti- $\alpha$ inhibin might be useful in the diagnosis of FATWO. Because confusion can arise with a sex cord stromal neoplasm, $\alpha$ inhibin positivity does not allow distinction between these two types of tumour, although in FATWO staining is usually weak in contrast to the diffuse strong positivity in sex cord stromal neoplasms. Another lesion that can morphologically resemble FATWO is the adenomatoid tumour. This neoplasm is of mesothelial derivation and clearly staining for calretinin is of no value in this distinction.

Transitional cell lesions of the ovary include benign, proliferating, low malignant potential and malignant Brenner tumour, and primary transitional cell carcinoma. Normal urothelium and urothelial neoplasms of the urinary tract express CD20. A recent study has found that most transitional cell lesions of the ovary fail to express CD20. ${ }^{94}$ The authors concluded that despite their morphological similarity to transitional cell carcinoma of the urinary tract, transitional cell lesions of the ovary are immunohistochemically distinct. They thought that the identification of pronounced CD20 expression in a malignant ovarian tumour with transitional features provides support for a metastasis from the urinary tract, rather than a primary ovarian surface epithelial neoplasm.

Pure sarcomas of the ovary are rare and a recent report described four cases of primary angiosarcoma. ${ }^{95}$ In these cases, the vascular nature of the tumour was not immediately apparent, but all were immunoreactive for vascular markers.

1 Ulbright TM, Roth LM, Stehman FB. Secondary ovarian neoplasia. A clinicopathologic study of 35 cases. Cancer 1984;53:1164-74

2 Lash RH, Hart WR. Intestinal adenocarcinomas metastatic to the ovaries. A clinicopathologic evaluation of 22 cases. Am 7 Surg Pathol 1987;11:114-21

3 Daya D, Nazerali L, Frank GL. Metastatic ovarian carcinoma of large intestinal origin simulating primary ovarian carcinoma. A clinicopathologic study of 25 cases. Am $\mathcal{F}$ Clin Pathol 1992;97:751-8.

4 Wauters CCAP, Smedts F, Gerrits LGM, et al. Keratins 7 and 20 as diagnostic markers of carcinomas metastatic to the ovary. Hum Pathol 1995;26:852-5.

5 Lagendijk JH, Mullink H, van Diest PJ, et al. Tracing the origin of adenocarcinomas with unknown primary using immunohistochemistry. Differential diagnosis between colonic and ovarian carcinomas as primary sites. Hum Pathol 1998;29:491-7.

6 Berezowski K, Stasny JF, Kornstein MJ. Cytokeratins 7 and 20 and carcinoembryonic antigen in ovarian and colonic carcinoma. Mod Pathol 1996;9:426-9. 
7 Loy TS, Calaluce RD, Keeney GL. Cytokeratin immunostaining in differentiating primary ovarian carcinoma from metastatic colonic adenocarcinoma. Mod Pathol 1996;9: 1040-4.

8 Ueda G, Sawada M, Ogawa H, et al. Immunohistochemical study of cytokeratin 7 for the differential diagnosis of adenocarcinoma in the ovary. Gynecol Oncol 1993;51:21923.

9 Young RH, Gilks CB, Scully RE. Mucinous tumors of the appendix associated with mucinous tumors of the ovary and pseudomyxoma peritonei. Am F Surg Pathol 1991;15: 415-29.

10 Seidman JD, Elsayed AM, Sobin LH, et al. Association of mucinous tumors of the ovary and appendix. A clinicopathologic study of 25 cases. Am f Surg Pathol 1993;17:2234.

11 Prayson RA, Hart WR, Petras RE. Pseudomyxoma peritonei: a clinicopathologic study of 19 cases with emphasis on site of origin and nature of associated ovarian tumors. Am f Surg Pathol 1994;18:591-603.

12 Ronnett BM, Kurman RJ, Zahn CM, et al. Pseudomyxoma peritonei in women: a clinicopathologic analysis of 30 cases with emphasis on site of origin, prognosis and relationship to ovarian mucinous tumors of low malignant potential. to ovarian mucinous tumors

13 Ronnett BM, Zahn CM, Kurman RJ, et al. Disseminated peritoneal adenomucinosis and peritoneal mucinous carcinomatosis: a clinicopathologic analysis of 109 cases with emphasis on distinguishing pathologic features, site of origin, prognosis and relationship to "pseudomyxoma peritonei”. Am F Surg Pathol 1995;19:1390-408.

14 Guerrieri C, Franlund B, Fristedt S, et al. Mucinous tumors of the vermiform appendix and ovary, and pseudomyxoma peritonei. Histogenetic implications of cytokeratin 7 expression. Hum Pathol 1997;28:1039-45.

15 Ronnett BM, Shmookler BM, Diener-West $M$, et al. Immunohistochemical evidence supporting the appendi-
ceal origin of pseudomyxoma peritonei in women. Int $f$ ceal origin of pseudomyxoma
Gynecol Pathol 1997;16:1-9.

16 Cuatrecasai M, Matrias-Guiu X, Prat J. Synchronous mucinous tumors of the appendix and the ovary associated with pseudomyxoma peritonei: a clinicopathologic study of six cases with comparative analysis of c-Ki-ras mutations. Am f Surg Pathol 1996;20:739-46.

17 Chuaqui RF, Zhuang Z, Emmert-Buck BR, et al. Genetic analysis of synchronous mucinous tumors of the ovary and appendix. Hum Pathol 1996;27:165-71.

18 Cheung ANY, Chiu PM, Khoo US. Is immunostaining with HAM56 antibody useful in identifying ovarian origin of
metastatic adenocarcinomas? Hum Pathol 1997;28:91-4.

19 Younes M, Katikaneni PR, Lechago LV, et al. HAM56 antibodies in the differential diagnosis between colorectal and gynecological malignancy [abstract 283]. Mod Pathol 1992; 5:49A.

20 Loy TS, Abshier J. Immunostaining with HAM56 in the diagnosis of adenocarcinomas. Mod Pathol 1993;6:473-5.

21 Fowler LJ, Maygarden SJ, Novotny DB. Human alveolar macrophage- 56 and carcinoembryonic antigen monoclonal antibodies in the differential diagnosis between primary antibodies in the differential diagnosis between primary
ovarian and metastatic gastrointestinal carcinomas. Hum Pathol 1994;25:666-70

22 Younes M, Katikaneni PR, Lechago LV, et al. HAM56 antibody: a tool in the differential diagnosis between colorectal and gynecological malignancy. Mod Pathol 1994;7: 396-400.

23 Nap M, Hammaarstrom ML, Bormer O, et al. Specificity and affinity of monoclonal antibodies against carcinoembryonic antigen. Cancer Res 1992;52:2329-39.

24 Pavelic ZP, Petrelli NJ, Herrera L, et al. D-14 monoclonal antibody to carcinoembryonic antigen: immunohistochemical analysis of formalin-fixed, paraffin-embedded human colorectal carcinoma, tumors of non-colorectal origin and normal tissues. $\mathcal{F}$ Cancer Res Clin Oncol 1990;116: gin an

25 Sheahan K, O'Brien MJ, Burke B, et al. Differential reactivities of carcinoembryonic antigen (CEA) and CEA-related monoclonal and polyclonal antibodies in common epithelial malignancies. Am f Clin Pathol 1990;94:157-64.

26 Hensen-Logmans SC, Schipper NW, Pods LG, et al. Statistical evaluation of antigen profiles in the differential diagnosis between colonic and ovarian adenocarcinomas. $f$ Clin Pathol 1988;41:644-9.

27 Loy TS, Quesenberry JT, Sharp SC. Distribution of CA125 in adenocarcinomas: an immunohistochemical study of in adenocarcinomas: an immunohistochem 481 cases. Am f Clin Pathol 1992;98:175-9.

28 Nouwen EJ, Pullet DE, Edekens MW, et al. Immunohistochemical localisation of placental alkaline phosphatase,
carcinoembryonic antigen, and cancer antigen 125 in normal and neoplastic human lung. Cancer Res 1986;46:866mal

29 Jacobs I, Bast RC. The Ca 125 tumour associated antigen: a view of the literature. Hum Reprod 1989;4:1-12.

30 Bateman AL, Al-Talib RK, Newman T, et al. Immunohistochemical phenotype of malignant mesothelioma: predictive value of CA125 and HBME-1 expression. Histopathology 1997;30:49-56.

31 Welshinger M, Yin BWT, Lloyd KO. Initial immunochemical characterisation of MX35 ovarian cancer antigen. Gynecol Oncol 1997;67:188-92.

32 Buist MR, Molthoff CFM, Kenemans P, et al. Distribution of OV-TL 3 and MOV18 in normal and malignant ovarian tissue. $\mathcal{F}$ Clin Pathol 1995;48:631-6.
33 Koonings PP, Campbell K, Mishell DR, et al. Relative frequency of primary ovarian neoplasms: a 10 year review. frequency of primary ovarian neo
Obstet Gynecol 1989;74:921-6.

34 Young RH, Scully RE. Ovarian sex cord-stromal tumors. Problems in differential diagnosis. Pathol Anпu 1988;23: 237-96.

35 Arora DS, Cooke IE, Ganesan TS, et al. Immunohistochemical expression of inhibin/activin subunits in epithelial 413-18.

36 McLachlan RI, Robertson DM, Healy DL, et al. Circulating immunoreactive inhibin levels during the normal menstrual cycle. $\mathcal{F}$ Clin Endocrinol Metab 1987;65:954-61.

37 McCluggage WG, Shanks JS, Whiteside C, et al. Immunohistochemical study of testicular sex cord-stromal tumors, including staining with anti-inhibin antibody. Am f Surg Pathol 1998;22:615-19.

38 Meunier H, Rivier C, Evans RM, et al. Gonadal and extragonadal expression of inhibin $\alpha, \beta \mathrm{A}$ and $\beta \mathrm{B}$ subunits in various tissues predicts diverse functions. Proc Natl Acad Sci U S A 1988;85:247-51

39 Crawford RJ, Hammond VE, Evans BA, et al. $\alpha$-inhibin gene expression occurs in the ovine adrenal cortex, and is
regulated by adrenocorticotrophin. Mol Endocrinol 1987;1: 699-706.

40 McCluggage WG, Burton J, Maxwell P, et al. Immunohistochemical staining of normal, hyperplastic and neoplastic adrenal cortex with a monoclonal antibody against $\alpha$ inhibin. f Clin Pathol 1998;51:114-16.

$41 \mathrm{McCl}$. histochemical staining of hepatocellular carcinoma with monoclonal antibody against inhibin. Histopathology 1997; mo:518-22.

42 McCluggage WG, Ashe P, McBride H, et al. Localisation of the cellular expression of inhibin in trophoblastic tissue. Histopathology 1998;32:252-6.

43 Cooke I, O'Brien MO, Charnock FM, et al. Inhibin as a marker for ovarian cancer. Br f Cancer 1995;71:1046-50.

44 Lappohn RE, Burger HG, Bouma J, et al. Inhibin as a marker for granulosa-cell tumors. N Engl f Med 1989;321: $790-1$.

45 McCluggage WG, Maxwell P, Sloan JM. Immunohistochemical staining of ovarian granulosa cell tumors with monoclonal antibody against inhibin. Hum Pathol 1997;28: 1034-8.

46 Matias-Guiu X, Pau C, Prat J. Mullerian inhibiting substance, alpha-inhibin and CD99 expression in sex cordstromal tumors and endometrioid ovarian carcinomas
resembling sex cord-stromal tumors. Hum Pathol 1998;29: resembling 840 .

47 Stewart CJR, Jeffers MD, Kennedy A. Diagnostic value of inhibin immunoreactivity in ovarian gonadal stromal tumors and their histological mimics. Histopathology 1997; 31:67-74.

48 Costa MJ, Ames PF, Walls J, et al. Inhibin immunohistochemistry applied to ovarian neoplasms: a novel, effective diagnostic tool. Hum Pathol 1997;28:1247-54.

49 Hildebrandt RH, Rouse RV, Longacre TA. Value of inhibin in the identification of granulosa cell tumors of the ovary. Hum Pathol 1997;28:1387-95.

50 Riopel MA, Perlman EJ, Seidman JD, et al. Inhibin and epithelial membrane antigen immunohistochemistry assist in the diagnosis of sex cord-stromal tumors and provide clues to the histogenesis of hypercalcaemic small cell carcinomas. Int f Gynecol Pathol 1998;17:46-53.

51 Hussong J, Crussi FG, Chou PM. Gonadoblastoma: immunohistochemical localization of Mullerian-inhibiting
substance, inhibin, WT-1 and p53. Mod Pathol 1997;10: 1101-5.

52 Pelkey TJ, Frierson HF, Mills SE, et al. The diagnostic utility of inhibin staining in ovarian neoplasms. Int f Gynecol Pathol 1998;17:97-105.

53 Flemming P, Wellmann A, Maschek H, et al. Monoclonal antibodies against inhibin represent key markers of adult granulosa cell tumors of the ovary even in their metastases. granulosa cell tumors of the ovary even
Am f Surg Pathol 1995;19:927-33.

54 Guerrieri C, Fraulund B, Malmstrom H, et al. Ovarian endometrioid carcinomas simulating sex cord-stromal tumors: a study using inhibin and cytokeratin 7. Int $\mathcal{f}$ Gynecol Pathol 1998;17:266-71

55 Rishi M, Howard LN, Bratthauer GL, et al. Use of monoclonal antibody against human inhibin as a marker for sex cord-stromal tumors of the ovary. Am f Surg Pathol 1997;21:583-9.

56 Kommoss F, Oliva E, Bhan AK, et al. Inhibin expression in ovarian tumors and tumor-like lesions: an immunohistochemical study. Mod Pathol 1998;11:656-64.

57 Zheng W, Sung CJ, Hanna I, et al. Alpha and beta subunits of inhibin/activin as sex cord-stromal differentiation markers. Int $\mathcal{f}$ Gynecol Pathol 1997;16:263-71.

58 McCluggage WG, Sloan JM, Murnaghan M, et al. Gynandroblastoma of ovary with juvenile granulosa cell component and heterologous intestinal type glands. Histopathology 1996;29:253-7.

59 Flemming P, Grothe W, Maschek H, et al. The site of inhibin production in ovarian neoplasms. Histopathology 1996;29: 465-8.

60 Healy DL, Burger HG, Bouma J, et al. Elevated serum inhibin concentrations in postmenopausal women with ovarian tumors. N Engl f Med 1993;329:1539-42.

61 McCluggage WG, Maxwell P. Adenocarcinomas of various sites may exhibit immunoreactivity with anti-inhibin antibodies. Histopathology 1999;35:216-20. 
62 Costa MJ, DeRose PB, Roth LM, et al. Immunohistochemical phenotype of ovarian granulosa cell tumors: absence of epithelial membrane

63 Otis CN, Powell JL, Barbuto D, et al. Intermediate filamentous proteins in adult granulosa cell tumors. Am f Surg Pathol 1992;16:962-8.

64 McCluggage WG, Sloan JM, Boyle DD, et al. Malignan fibrothecomatous tumour of the ovary. Diagnostic value of anti-inhibin immunostaining. F Clin Pathol 1998;51:86871 .

65 McCluggage WG. Uterine tumours resembling ovarian sex cord tumours: immunohistochemical evidence for true sex cord differentiation. Histopathology 1999;34:373-80.

66 Krishnamurthy S, Jungbloth AA, Busan KJ, et al. Uterine tumors resembling ovarian sex-cord tumors have an immunophenotype consistent with true sex-cord differentiation. Am 7 Surg Pathol 1998;22:1078-82.

67 Baker RJ, Hildebrandt RH, Rouse RV, et al. Inhibin and CD99 (MIC2) expression in uterine stromal neoplasms with sex cord-like elements. Hum Pathol 1999;30:671-9.

68 McCluggage WG, Patterson A, White J, et al. Immunocytochemical staining of ovarian cyst aspirates with monoclona antibody against inhibin. Cytopathology 1998;9:336-42.

69 Arora DS, Cooke IE, Ganesan TS, et al. Immunohistochemical expression of inhibin/activin subunits in epithelial and granulosa cell tumours of the ovary. F Pathol 1997;181 413-18.

70 Weidner N, Tjoe J. Immunohistochemical profile of monoclonal antibody 013: antibody that recognises glycoprotein $30 / 32$ MIC2 and is useful in diagnosing Ewings sarcoma and peripheral neuroepithelioma. Am 7 Surg Pathol 1994;18:486-94.

71 Ambros TM, Ambros PF, Strehl S, et al. MIC2 is a specific marker for Ewing's sarcoma and peripheral neuroectodermal tumors. Cancer 1991;67:1886-93.

72 Stevenson AJ, Chatten J, Bertoni F, et al. CD99 (p30/32 MIC2) neuroectodermal/Ewing's sarcoma antigen as an immunohistochemical marker: review of more than 600 immunohistochemical marker: review of more than 600 tumours and the literature

73 Loo KT, Leung AKF, Chan JKC. Immunohistochemical staining of ovarian granulosa cell tumours with MIC2 antibody. Histopathology 1995;27:388-90.

74 Gordon MD, Corless C, Renshaw AA, et al. CD99, keratin and vimentin staining of sex cord-stromal tumors, normal ovary and testis. Mod Pathol 1998;11:769-73.

75 Kawauchi S, Fukuda T, Miyamoto S, et al. Peripheral primitive neuroectodernal tumor of the ovary confirmed by CD99 immunostaining, karyotypic analysis and RT-PCR for EWS/FLI-1 chimeric mRNA. Am $\mathcal{f}$ Surg Pathol 1998;22:1417-22.

76 Blessing K, Sanders DS, Grant JJ. Comparison of immunohistochemical staining of the novel antibody melan-A with S100 protein and HMB-45 in malignant melanoma and melanoma variants. Histopathology 1998;32:139-46.

77 Busam KJ, Iversen K, Coplan KA, et al. Immunoreactivity for A103, an antibody to melan-A (Mart-1) in adrenocortifor A103, an antibody to melan-A (Mart-1) in adrenocorti63.

78 Kuroda T, Lee MM, Ragin RC, et al. Mullerian inhibiting substance production and clearage is modulated by gonadotrophins and steroids. Endocrinology 1991;129: 2985-92.

79 Behringer RR, Finegold MJ, Cate RL. Mullerian inhibiting substance function during mammalian sexual development. Cell 1994;79:415-25.

80 Gustafson ML, Lee MM, Scully RE, et al. Mullerian inhibiting substance as a marker for sex-cord tumor. $N$ Engl $\mathcal{F}$ Med 1992;326:466-71.

81 Silverman LA, Gitelman SE. Immunoreactive inhibin, mullerian inhibitory substance and activin as biochemical markers for juvenile granulosa cell tumors. F Pediatr 1996; 129:918-21

82 Ivell R. Biology of the relaxin-like factor (RLF). Rev Reprod 1997;2:133-8

83 83Bamberger AM, Ivell R, Balvers M. Relaxin-like factor (RLF): a new specific marker for Leydig cells in the ovary. Int 7 Gynecol Pathol 1999;18:163-8.

84 Doglioni C, Dei Tos AP, Laurino L. Calretinin: a novel immunocytochemical marker for mesothelioma. Am 7 Surg Pathol 1996;20:1037-46.

85 Young RH, Perez-Atayde AR, Scully RE. Ovarian SertoliLeydig cell tumour with retiform and heterologous elements. Am f Surg Pathol 1984;8:709-18.

86 Gagnou S, Tetu B, Silva EG, et al. Frequency of alpha-fetoprotein production by Sertoli-Leydig cell tumors of the ovary: an immunohistochemical study of eight cases. Mod Pathol 1989:2:63-7.

87 Hammad A, Jasnosz KM, Olson PR. Expression of alpha-fetoprotein by ovarian Sertoli-Leydig cell tumors. Arch Pathol Lab Med 1995;169:1075-9.

88 Mooney EE, Nogales FF, Tavassoli FA. Hepatocytic differentiation in retiform Sertoli-Leydig cell tumors: distinguishing a heterologous element from Leydig cells. Hum Pathol 1999;30:611-17.

89 Ahmed E, Young RH, Scully RE. Adult granulosa cell tumour of the ovary with foci of hepatic cell differentiation. Am 7 Surg Pathol 1999;23:1089-93.

90 Maida Y, Kyo S, Takakura M, et al. Ovarian endometrioid adenocarcinoma with ectopic production of $\alpha$-fetoprotein. Gynecol Oncol 1998;71:133-6.

91 Aquirre P, Thor A, Scully RE. Ovarian small cell carcinoma Histogenic considerations based on immunohistochemical and other findings. Am f Clin Pathol 1989;92:140-9.

92 Demopoulos RI, Sitelman A, Flotte T, et al. Ultrastructural study of a female adnexal tumor of probable wolffian origin. Cancer 1980;46:2273-80.

93 Devouassoux-Shisheboran M, Silver SA, Tavassoli FA. Wolffian adnexal tumor, so-called female adnexal tumor of probable wolffian origin (FATWO): immunohistochemical evidence in support of a wolffian origin. Hum Pathol 1999; 30:856-63.

94 Soslow RA, Rouse RV, Hendrickson MR, et al. Transitional cell neoplasms of the ovary and urinary bladder: a comparative immunohistochemical analysis. Int $\mathcal{f}$ Gynecol Pathol 1996;15:257-65.

95 Nucci MR, Krausz T, Lifschitz-Mercer B, et al. Angiosarcoma of the ovary. Clinicopathologic and immunohistochemical analysis of four cases with a broad morphologic spectrum. Am F Surg Pathol 1998;22:620-30.

\section{WHAT'S YOUR VIEW?}

\section{Pathology Interactive: useful or useless?}

\section{To make Pathology Interactive more useful tool to help you in your CPD}

\section{... we need your views}

Please take time to complete a self completion questionnaire and fax it back to us

Questionnaire available for printing out on:

Pathology Interactive CD Vol 1 issue3 (Dec 1999)

Pathology Interactive CD Vol 22000

Fournal of Clinical Pathology website - www.jclinpath.com

Fax completed forms to Natalie Davies, Editorial Assistant, Journal of Clinical Pathology (+44 (0)20 7383 6668).

Your time and help are appreciated. We especially thank all those ACP members who returned questionnaires circulated in the September 1999 journal issue for their valuable feedback.

Pathology Interactive 2000 offers up to three CPD credits per article; later issues feature case study and picture quiz formats 